\title{
Riparian Zones and Pollination Service: A Case Study from Coffee- Agrosystem Along River Cauvery, South India
}

\author{
N. Deepthi*†, B.C. Nagaraja* and M. Paramesha** \\ *Department of Environmental Science, Bangalore University, Jnanabharathi Campus, Bangalore-560 056, India \\ **St. Joseph's College (Autonomous), 36, Langford Road, Langford Gardens, Bangalore-560 027, India \\ †Corresponding author: N. Deepthi; deepthi.padma@gmail.com
}

Nat. Env. \& Poll. Tech

Website: www.neptjournal.com

Received: 03-10-2019

Revised: $07-11-2019$

Accepted: 11-12-2019

Key Words:

Pollination

Riparian zone

Coffee plantation

Pollinators

\begin{abstract}
The study aims to understand the influence of pollinator visitation rate to coffee plantations located along the riparian zones of river Cauvery in Karnataka, using distance as a criterion. Plots were fixed at $10 \mathrm{~m}, 30 \mathrm{~m}$ and $60 \mathrm{~m}$ points from the edge of riparian zone towards the coffee plantations. In each of these three points, five plants were selected. In each plant, four branches with approximately six inflorescences per branch were observed for 15 minutes and the visitation rate of selected floral visitors to Coffea canephora was recorded. To understand if a riparian zone was a suitable pollinator habitat, bee colonies in the riparian zone were identified through a transect of approximately $500 \mathrm{~m}$ adjacent to the study plot. The total number of bee visits for Apis dorsata, Apis cerana, Tetragonula iridipennis and Apis florea was 18,100 for an observation time of 9540 minutes. A. dorsata and $A$. cerana were the main contributors to the total number of visits. The visitation rate of pollinators, $A$. cerana and $A$. dorsata decreased with increase in distance from the riparian zone. Additionally, colonies of $A$. cerana and $A$. dorsata were found in the riparian zones indicating riparian zones as potential pollinator habitats. A negative relationship has been observed between total species visits and distance indicating a reduction in species visits with increased distance from the riparian zone. Conservation of riparian zones increases pollination service to adjacent coffee plantations along with a multitude of other ecosystem services.
\end{abstract}

\section{INTRODUCTION}

Riparian zones are interfaces between terrestrial and aquatic ecosystems. They cannot be delineated easily (Gregory et al. 1991) and the width varies up to several metres. They are ecotones with high biodiversity and productivity in contrast to the larger landscape (Naiman et al. 1998). Moreover, they are high energy systems, which are favoured by humans for food, water, dwelling sites, recreation and other uses (Johnson \& Haight 1984). Further, they provide multiple ecosystem services such as water purification, nutrient removal, riverbank stabilization, act as corridors, habitat provider, fodder, fuelwood and others (Jose 2009, Naiman et al. 2010). This diverse ecosystem is under threat and is one of the major areas where biodiversity is being lost (Sparovek et al. 2002), which in turn affects the delivery of ecosystem services. Riparian zones are threatened by agricultural land expansion (Sunil et al. 2010), extraction of water, grazing, waste dumping and expanding human habitations (Naiman et al. 2010).

Food production is an ecosystem service which depends on water, soil formation, pollination and others. Changes in pollination service will affect food production and impact human well-being (Millennium Ecosystem Assessment 2005, Potts et al. 2016). There is a global decline in managed and wild pollinators in agricultural landscapes (Roubik et al. 2018) even though animal pollinators contribute $15-30 \%$ of global food production and bees (Apis) being one of the important pollinators of most crops (Roubik 1995, Potts et al. 2010). Agricultural crop productivity depends at least partially on unmanaged or wild pollinators from semi-natural habitats (Kremen et al. 2002, Kremen et al. 2004). Natural landscapes like riparian zones could be potential sources of pollinators to nearby agricultural land. But studies considering riparian zones as exclusively pollinator sources are limited probably because of the complex nature of riparian zones such as varying width, habitats, flowering pattern, accessibility and others. Most studies tend to combine other natural habitats like forests along with riparian zone to study pollination. For instance, in California pollination services to hybrid sunflower (Helianthus annuus), almond (Prunus dulcis) and muskmelon (Cucumis melo) was higher when the farmland was located close to natural habitats, such as riparian, oak woodland, chaparral and mixed oak (Greenleaf \& 
Kremen 2006, Ricketts et al. 2008). Similarly, in Costa Rica pollinator visits from riparian zones and forest fragments to coffee farms reduced with increasing distance (Ricketts 2004), while in Portugal, riparian scrubland and riparian forest supported higher pollination services in comparison to other land uses such as agricultural land, mixed forest, coniferous forest and eucalyptus forest (Santos et al. 2018).

In India, there are no specific studies on assessment of riparian ecosystem services but fewer studies restricted to the biodiversity of the riparian zone (Sunil et al. 2016). Besides, there are no specific guidelines/policies governing riparian zones in India (Sunil et al. 2011). Studies on the riparian zone as a potential pollination services provider to adjacent agricultural systems are limited in India and hence an attempt is being made to study the same along the riparian zones of river Cauvery in Kodagu district, Karnataka. With this background, the study addresses the research question; does the proximity of riparian zone influence visitation rate of pollinators to Coffea canephora?

\section{MATERIALS AND METHODS}

\section{Study Area}

Cauvery is one of the major rivers of peninsular India and supports huge populations in Karnataka and Tamil Nadu for domestic, irrigation, industries and hydropower generation. It originates $\left(12^{\circ} 25^{\prime} \mathrm{N}, 75^{\circ} 34^{\prime} \mathrm{E}, 1341 \mathrm{~m}\right)$ in the Western Ghats in Karnataka and flows through the state of Tamil Nadu before entering the Bay of Bengal (GOI 2014). It flows for about $320 \mathrm{~km}$ in Karnataka, while its total length is approximately $800 \mathrm{~km}$. Its basin $\left(81,155 \mathrm{~km}^{2}\right)$ is spread across Tamil Nadu and Pondicherry (54\%), Karnataka (42\%) and Kerala (4\%) (Jayaram 2000). The upstream of the river in Karnataka flows through the district of Kodagu well-known for its coffee plantations. Area of Kodagu district is approximately 4,102 $\mathrm{km}^{2}$ and $33 \%$ of it is under coffee-agroforestry (Garcia et al. 2010). Two popular varieties of coffee, Coffea arabica and Coffea canephora are cultivated, with the latter having the highest area under cultivation (56,000 ha) according to Coffee Board of India. Rest of the land area in the district is under paddy cultivation and protected areas either as sacred grooves, reserve forest, wildlife sanctuaries and national park. In coffee-agroforestry system, coffee is cultivated under the shade of native or exotic tree species, additionally, pepper vines are grown on shade trees as a supplementary crop.

\section{Methods}

The study was carried out during March 2017 in coffee-agrosystems located along river Cauvery, Kodagu district, India. Suitable coffee-agroforests were selected at every $8 \mathrm{~km}$

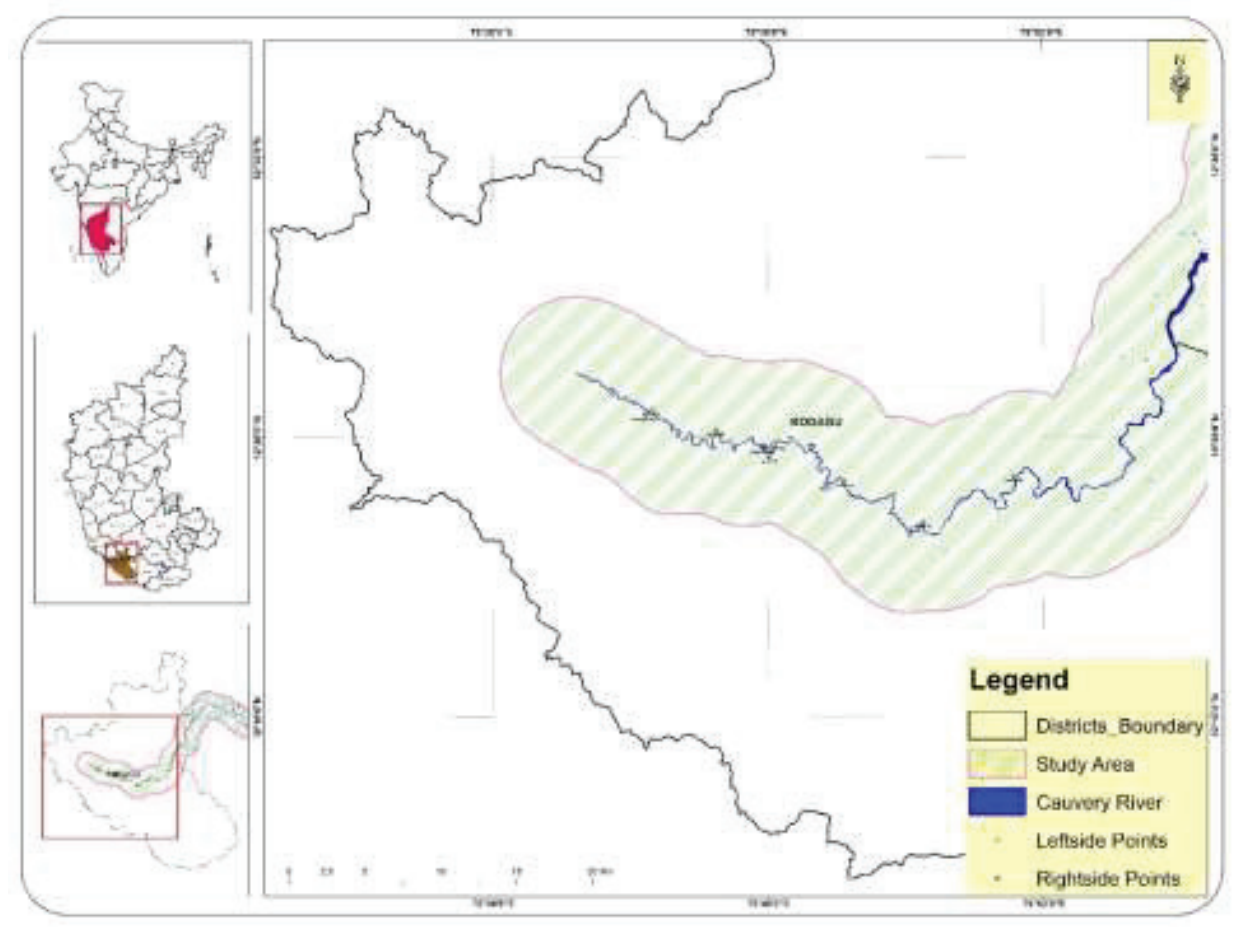

Fig. 1: The study area. 
interval $(\mathrm{n}=11)$ along the riparian zone which was spread on both left $(n=6)$ and right $(n=5)$ bank of the river (Fig. 1$)$. The study used distance as a criterion to understand pollination service to crops (Ricketts 2004, Winfree \& Kremen 2009). In each sampling plot, from the edge of riparian zone 10, 30 and $60 \mathrm{~m}$ points were fixed to understand the pollinator visitation to Coffea canephora inflorescence. In each of these three points, five plants (each at $20 \mathrm{~m}$ interval) were marked (Fig. 2). In each plant, four branches with approximately six inflorescences per branch were observed for 15 minutes (Boreux et al. 2013).

During the observation period, the visitation rate of selected floral visitors to Coffea canephora was recorded. A bee visit meant a bee visiting a flower for more than one second duration (Kremen et al. 2004) which could be for either collecting resources or pollination (Ricketts 2004). The number of visits was very low before 07:00 and after 13:00 hrs, hence the sampling time was standardised to 07:00 to 13:00 hrs. These observational plots are suitable for studying pollinator abundance and richness in a specified area (Westphal et al. 2008).

The entire study was carried out only in irrigated coffee plantations because during mass flowering no bee visits were observed in almost half of the plantations studied by Boreux et al. (2013) in Kodagu. Plots beyond $60 \mathrm{~m}$ were not chosen as blooming was not observed on the day of the study, because of the variation in irrigation patterns. Also, with increasing distance, there could be chances of bees visiting from the nearby forest fragments which could hamper the objective of the study. Furthermore, these coffee-agroforests did not have any bee boxes in the surroundings that could hamper the objective of the study.
The pollination service rendered by riparian forest along river Cauvery was studied by using indicator species, coffee plants (Coffee canephora) and bees. Coffee canephora, an evergreen shrub or small tree is cultivated extensively in Kodagu district. It is locally known as Robusta coffee and can grow up to $10 \mathrm{~m}$ with a shallow root system. It requires an average rainfall of $1800 \mathrm{~mm} /$ year, temperature between $24^{\circ} \mathrm{C}$ and $30^{\circ} \mathrm{C}$ and well-drained, loamy, slightly acidic and rich in humus soil. It begins yielding 2-3 years after planting. It requires about 4-8 weeks of a dry period, which builds water stress and helps in initiating flowering (Nair 2010).

In Kodagu district, flowering is initiated due to summer rains in February and March. If rains are delayed, irrigation is adopted to initiate flowering. One to three inflorescences are borne on each leaf axil, with each inflorescence consisting of three to six flowers, stalkless to stalked, with stalks up to $7 \mathrm{~mm}$. The blooming attracts many pollinators such as bees, butterflies and other insects. It is a wind-pollinated crop but entomophilous pollination enhances fruit set and increases yield (Roubik 2002).

Previous studies by Ricketts (2004) and Krishnan et al. (2012) found Apis species to be the highest visitor to Coffee. Hence, Apis cerana (Asiatic honey bee), Apis dorsata (Giant honey bee), Apis florea (Dwarf honey bee) and Tetragonula iridipennis (Stingless bee) were selected for the study. To understand if the riparian zone was a suitable pollinator habitat, bee colonies in the riparian zone were identified through a transect of $500 \mathrm{~m}$ adjacent to the study plot. Transect method shows species richness as well as composition (Westphal et al. 2008). The data related to coffee pollinators, location of bee colonies, yield, etc., were also collected from coffee farmers and workers through informal interviews to

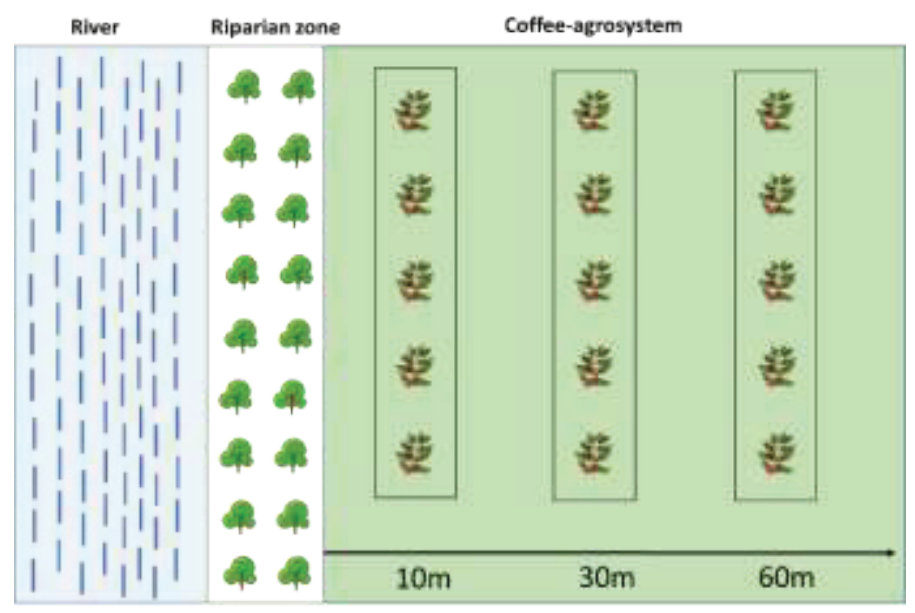

Fig. 2: Sampling design for pollination study in the coffee-agrosystem landscape of River Cauvery. 
understand community perception towards bee pollination and its habitat.

\section{RESULTS AND DISCUSSION}

The total number of bee visits for the four selected species was 18,100 for an observation time of 9,540 minutes. Klein et al. (2003) recorded 2269 individuals with an observation time of 1125 minutes and the trend is almost similar to the present study. Species abundance based on bee visits was in the following order: Apis dorsata, Apis cerana, Tetragonula iridipennis and Apis florea (Table 1). Apis dorsata and Apis cerana were the main contributors to the total number of visits. It was also observed that apart from Apis species, lepidopterans and dipterans also visited coffee inflorescence but their numbers were very low. Krishnan et al. (2012) observed $58 \%$ of Apis dorsata visits to Coffea canephora in Kodagu.

The distance of coffee plants from the riparian zone had a significant impact on the pollinator abundance for two species $A$. cerana and $A$. dorsata. The average number of visits for $15 \mathrm{~min}$ per branch for A. cerana decreased with increasing distance $(10 \mathrm{~m}$ to $60 \mathrm{~m})$ from the riparian zone. A. dorsata showed consistent visits for $10 \mathrm{~m}$ and 30 $\mathrm{m}$, while for $60 \mathrm{~m}$ there was a decrease in visits. However, T. iridipennis exhibited increasing visits with increase in distance. At $10 \mathrm{~m}$ distance, the visits were nil, while at 30 $\mathrm{m}$ and $60 \mathrm{~m}$ the visits were just one. A. florea exhibited low visitation rate ( $\leq 1$ visit) at all the three distances. Thus, $A$. cerana and $A$. dorsata species abundance was higher closer to the edge of the riparian zone (Fig. 3). Total species visits were log-transformed to reduce the space between units. A negative relationship has been observed between total species visits and distance indicating a reduction in species visits with increased distance from the riparian zone. A similar observation was recorded in Costa Rica, bee species richness in coffee farms reduced as the distance from the riparian forest increased (Ricketts 2004).

In the colony count study, for a total of $5500 \mathrm{~m}$ transect in the riparian zone, colonies of A. dorsata, A. cerana and A. florea were observed (Table 2). T. iridipennis was absent in the transect studied. Higher number of colonies have been observed for A. dorsata, while A. florea least. Colonies of

Table 1: Species wise bee visits to Coffea canephora inflorescence.

\begin{tabular}{|lll|}
\hline Bee species & No. of visits & $(\%)$ \\
\hline Apis cerana Fabricius & 8543 & 47 \\
Apis dorsata Fabricius & 9070 & 50 \\
Apis florea Fabricius & 158 & 1 \\
Tetragonula iridipennis Smith & 329 & 2 \\
Total & 18100 & \\
\hline
\end{tabular}

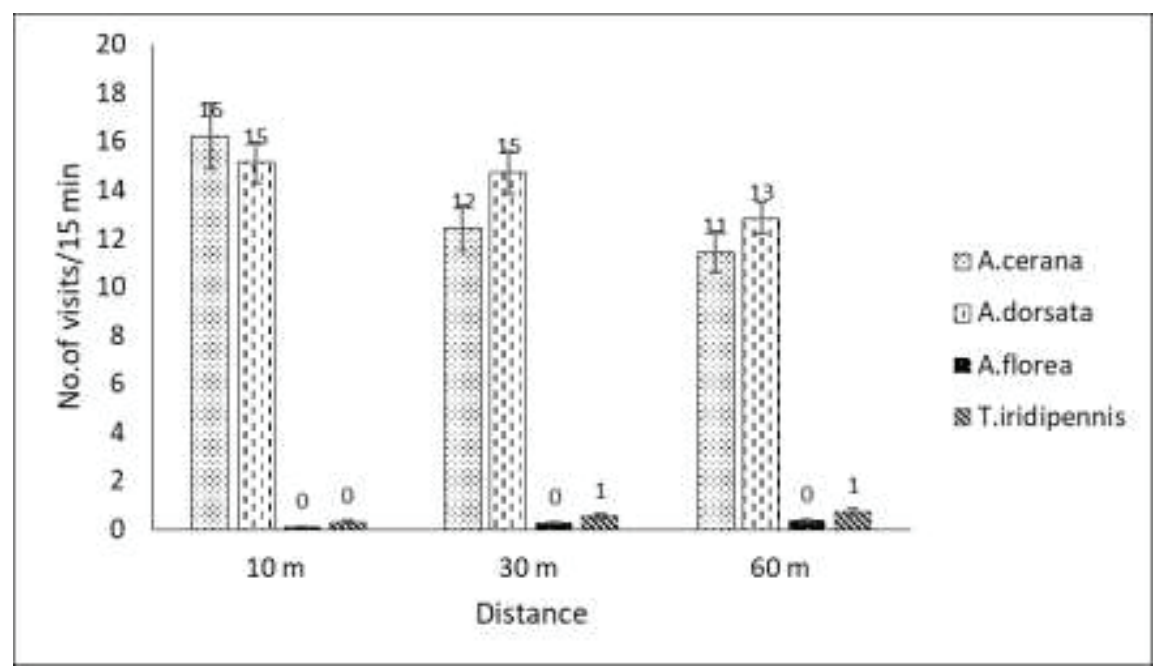

Fig. 3: Proximity-wise mean bee visits/15 minutes to Coffee canephora at increasing distance from the edge of the riparian zone. 
Table 2: Bee colonies found in the riparian zone adjacent to study plots.

\begin{tabular}{|lll|}
\hline Study species & No. of colonies & Nesting site in the riparian zone \\
\hline Apis cerana & 4 & Tree cavities, fallen logs and lateral caving in the river bank \\
Apis dorsata & 8 & Branches of tall trees and bridges. \\
Apis florea & 2 & Branches of shrubs \\
\hline
\end{tabular}

A. dorsata were found on branches of tall trees and under the bridges. Paar et al. (2000) also recorded A. dorsata colonies were restricted to forests due to their habit of nesting at greater heights such as tall trees. Thus, riparian zones are found to be suitable nesting habitat for A. dorsata species.

Qualitative interviews with coffee farmers and workers revealed $A$. dorsata built colonies in riparian zones during summers which were the flowering season for coffee. A mixed response was obtained towards the presence of colonies during rains, some mentioned that the colonies moved towards forests, while some were not aware of it. Majority of the respondents strongly agreed coffee fruit set was enhanced by bee pollination particularly $A$. dorsata. Awareness among communities on pollinators and their habitats will increase their income from coffee as well as promote pollinator habitat conservation in the riparian landscape.

Unlike other coffee-agroforests in the region, the ones that are adjacent to the river have multiple advantages in terms of water availability as well as pollinators. Hence, promoting riparian habitat heterogeneity such as increasing floral and nesting resources, wildflower margins and hedgerows increases pollinator (Santos et al. 2018) richness and abundance, further increasing crop productivity. Further studies could compare the crop productivity to the number of bee visits in the riparian landscape.

\section{CONCLUSION}

Natural habitats and agricultural landscapes are ecologically interconnected as pollinator diversity is essential for entomophilous crops (Kremen et al. 2002). Among other factors such as species of natural pollinators, foraging range, attractive flowers, etc., farmland distance to the natural habitat of wild pollinators plays a significant role in pollination success. The study concludes (i) Coffee-agrosystems adjacent to riparian zones observed higher A. dorsata visits, a significant pollinator of Coffea canephora, (ii) Riparian zones are important habitat for pollinators mainly $A$. dorsata and A. cerana, apart from other forest fragments present across Kodagu district. Thus, the conservation of riparian zones can increase pollination service to the coffee farms, enhance crop productivity and increase economic gains.

\section{ACKNOWLEDGEMENT}

We thank Jeevan Naliyammana, Vimhaseno Neikha and Subbramani for assisting in fieldwork.

\section{REFERENCES}

Boreux, V., Krishnan, S., Cheppudira, K. G. and Ghazoul, J. 2013. Impact of forest fragments on bee visits and fruit set in rain-fed and irrigated coffee agro-forests. Agriculture, Ecosystems \& Environment, 172: 42-48.

Garcia, C. A., Bhagwat, S. A., Ghazoul, J., Nath, C. D., Nanaya, K. M., Kushalappa, C. G., Raghuramulu, Y., Nasi, R. and Vaast, P. 2010. Biodiversity conservation in agricultural landscapes: challenges and opportunities of coffee agroforests in the Western Ghats, India. Conservation Biology, 24(2): 479-488.

Government of India 2014. Cauvery basin. Ministry of Water Resources, Government of India (GOI). Retrieved from www.india-wris.nrsc.gov. in, on $1^{\text {st }}$ November, 2015.

Greenleaf, S. S. and Kremen, C. 2006. Wild bees enhance honey bees' pollination of hybrid sunflower. Proceedings of the National Academy of Sciences, 103(37): 13890-13895.

Gregory, S.V., Swanson, F.J., McKee, W.A. and Cummins, K.W. 1991. An ecosystem perspective of riparian zones. BioScience, 41(8): 540-551.

Jayaram, K.C. 2000. Kaveri Riverine System: An Environmental Study. The Madras Science Foundation, Chennai.

Johnson, R.R. and Haight, L.T. 1984. Riparian problems and initiatives in the American Southwest: A regional perspective. In: Warner, R.E., \& Hendrix, K.M (eds). California Riparian Systems: Ecology, Conservation and Productive Management. University of California Press, Berkley.

Jose, S. 2009. Agroforestry for ecosystem services and environmental benefits: An overview. Agroforestry Systems, 76(1): 1-10.

Klein, A. M., Steffan Dewenter, I. and Tscharntke, T. 2003. Bee pollination and fruit set of Coffea arabica and C. canephora (Rubiaceae). American Journal of Botany, 90(1): 153-157.

Kremen, C., Williams, N. M. and Thorp, R. W. 2002. Crop pollination from native bees at risk from agricultural intensification. Proceedings of the National Academy of Sciences, 99(26): 16812-16816.

Kremen, C., Williams, N.M., Bugg, R.L., Fay, J.P. and Thorp, R.W. 2004. The area requirements of an ecosystem service: Crop pollination by native bee communities in California. Ecology Letters, 7(11): 1109-1119.

Krishnan, S., Kushalappa, C.G., Shaanker, R.U. and Ghazoul, J. 2012. Status of pollinators and their efficiency in coffee fruit set in a fragmented landscape mosaic in South India. Basic and Applied Ecology, 13(3), 277-285.

Millennium Ecosystem Assessment 2005. Ecosystems and Human Well-being: Synthesis. Island Press, Washington, DC.

Naiman, R.J., Decamps, H. and McClain, M.E. 2010. Riparia: Ecology, Conservation, and Management of Streamside Communities. Elsevier, USA.

Naiman, R.J., Fetherston, K.L., McKay, S.J. and Chen, J. 1998. Riparian forests. In: Naiman, R.J., and Bilby, R.E. (eds). River Ecology and Management: Lessons from the Pacific Coastal Ecoregion, Springer-Verlag, New York. 
Nair, K.P. 2010. The Agronomy and Economy of Important Tree Crops of the Developing World. Elsevier, USA.

Paar, J., Oldroyd, B.P. and Kastberger, G. 2000. Entomology: Giant honeybees return to their nest sites. Nature, 406(6795): 475 .

Potts, S.G., Biesmeijer, J.C., Kremen, C., Neumann, P., Schweiger, O. and Kunin, W. E. 2010. Global pollinator declines: Trends, impacts and drivers. Trends in Ecology \& Evolution, 25(6): 345-353.

Potts, S.G., Ngo, H.T., Biesmeijer, J.C., Breeze, T.D., Dicks, L.V., Garibaldi, L.A., Hill, R., Settele, J. and Vanbergen, A. 2016. The assessment report of the Intergovernmental Science-Policy Platform on Biodiversity and Ecosystem Services on Pollinators, Pollination And Food Production. The Intergovernmental Science-Policy Platform on Biodiversity and Ecosystem Services.

Ricketts, T.H. 2004. Tropical forest fragments enhance pollinator activity in nearby coffee crops. Conservation Biology, 18(5): 1262-1271.

Ricketts, T.H., Regetz, J., Steffan Dewenter, I., Cunningham, S. A., Kremen, C., Bogdanski, A., Gemmill-Herren, B., Greenleaf, S.S., Klein, A. M., Mayfield, M. M. and Morandin, L.A. 2008. Landscape effects on crop pollination services: Are there general patterns? Ecology Letters, 11(5): 499-515.

Roubik, D.W. 1995. Pollination of cultivated plants in the tropics (No. 118). Food \& Agriculture Organisation of the United Nations, Rome.

Roubik, D.W. 2002. Tropical agriculture: The value of bees to the coffee harvest. Nature, 417(6890): 708.

Roubik, D.W., Sihag, R.C., Kevan, P.G., Garibaldi, L.A., Cunningham, S.A., Aizen, M.A., Packer, L., Harder, L.D., Krell, R., Biddinger, D.J. and Rajotte, E.G. 2018. The pollination of cultivated plants: A com- pendium for practitioners. Vol 1. Food and Agriculture Organization of the United Nations, Rome.

Santos, A., Fernandes, M.R., Aguiar, F.C., Branco, M.R. and Ferreira, M.T. 2018. Effects of riverine landscape changes on pollination services: A case study on the River Minho, Portugal. Ecological Indicators, 89: 656-666.

Sparovek, G., Ranieri S. B. L., Gassner, A., De Maria, I.C., Schnug, E., dos Santos, R.F. and Joubert, A. 2002. A conceptual framework for the definition of the optimal width of riparian forests. Agriculture, Ecosystems \& Environment, 90(2): 169-175.

Sunil, C., Somashekar, R. K. and Nagaraja, B. C. 2010. Riparian vegetation assessment of Cauvery River basin of South India. Environmental Monitoring and Assessment 170(1-4): 545-553.

Sunil, C., Somashekar, R.K. and Nagaraja, B.C. 2011. Impact of anthropogenic disturbances on riparian forest ecology and ecosystem services in Southern India. International Journal of Biodiversity Science, Ecosystem Services \& Management, 7(4): 273-282.

Sunil, C., Somashekar, R.K. and Nagaraja, B.C. 2016. Diversity and composition of riparian vegetation across forest and agroecosystem landscapes of river Cauvery, southern India. Tropical Ecology, 57(2): 343-354.

Westphal, C., Bommarco, R., Carre, G., Lamborn, E., Morison, N., Petanidou, T., Potts, S. G., Roberts, S.P., Szentgyorgyi, H., Tscheulin, T. and Vaissiere, B.E. 2008. Measuring bee diversity in different European habitats and biogeographical regions. Ecological Monographs, 78(4): 653-671.

Winfree, R. and Kremen, C. 2009. Are ecosystem services stabilized by differences among species? A test using crop pollination. Proceedings of the Royal Society B: Biological Sciences, 276(1655): 229-237. 